\title{
Molecular Diagnostic Assay for Detection of the Butternut Canker Pathogen Sirococcus clavigignenti-juglandacearum
}

\author{
K. D. Broders and G. J. Boland, School of Environmental Sciences, University of Guelph, Guelph ON, Canada \\ N1G 2W1
}

\begin{abstract}
Broders, K. D., and Boland, G. J. 2010. Molecular diagnostic assay for detection of the butternut canker pathogen Sirococcus clavigignenti-juglandacearum. Plant Dis. 94:952-958.

Butternut canker, caused by the fungal pathogen Sirococcus clavigignenti-juglandacearum, is present throughout the range of butternut (Juglans cinerea) and is the primary cause for its decline. A quick and reliable method for identification of S. clavigignenti-juglandacearum would provide a valuable tool for the detection of the pathogen on propagative material to avoid spread, as well as assist studies targeted at the epidemiology of this pathogen, in particular the dissemination of the pathogen by seeds of the butternut. The objective of this study was to develop a diagnostic assay to detect $S$. clavigignenti-juglandacearum in butternut plant tissue. The primers were developed using an alignment of internal transcribed spacer (ITS) sequences from isolates of $S$. clavigignenti-juglandacearum and several closely related species. These primers were tested on J. cinerea, 48 isolates of S. clavigignenti-juglandacearum recovered from diseased trees, and 26 species of other fungi recovered from butternut tissue. The primers amplified a product from the DNA of all isolates of $S$. clavigignenti-juglandacearum, detected its DNA at a concentration as low as $1 \mathrm{pg} / \mu \mathrm{l}$, and detected the pathogen at a concentration of $1 \times 10^{3}$ spore/ml. The primers developed in this study will be a valuable tool for the detection of $S$. clavigignenti-juglandacearum present on butternut seeds, and as a rapid diagnostic tool for early detection of the pathogen on butternut trees.
\end{abstract}

Butternut (Juglans cinerea L.) is a medium-sized hardwood tree that is native to the eastern North American forests. In recent years, this tree has been decimated by the fungal pathogen Sirococcus clavigignenti-juglandacearum N.B. Nair, Kostichka \& J.E. Kuntz, which causes butternut canker. Butternut canker was first reported from southwestern Wisconsin in 1967 (24), and the pathogen causing the disease was described for the first time in 1979 (16). It is unclear how long the canker disease has existed in North America, but research reported by Furnier et al. (3) suggests that S. clavigignentijuglandacearum was recently introduced into North America. Evidence supporting the hypothesis of a recent introduction includes the following: numerous recent first reports of the occurrence of the disease and its documented rapid expansion in North America, lack of genetic variation in the pathogen population (3), symptoms that are an obvious diagnostic

Corresponding author: G. J. Boland

E-mail: gboland@uoguelph.ca

Accepted for publication 26 April 2010.

doi:10.1094/PDIS-94-8-0952

(C) 2010 The American Phytopathological Society feature and therefore not likely overlooked in the past (16), and the fact that disease-free trees are rarely found within affected populations of native butternut (20).

S. clavigignenti-juglandacearum grows under the bark layer after the spores have found an entry point. The fungus then forms thin, black stromatic tissue under the bark, and eventually forms a number of stromatal columns composed of interwoven mycelia, which lift the dying bark layers of the tree until they rupture (33). The pathogen is primarily spread via rain splash and wind dispersal (33). Longdistance movement of the pathogen likely takes place by insect transmission $(5,11)$ and within infected seed of butternut and black walnut (Juglans nigra L.) (9). In addition, the fungus can continue to produce spores on dead trees for up to 2 years (33). S. clavigignenti-juglandacearum may also be able to infect and colonize other hardwood species. Ostry and Moore (18) found that in greenhouse inoculations, the pathogen was able to colonize several genera of hardwoods, including Juglans, Carya, Quercus, Castenea, and Prunus, and several commercially important Persian walnut $(J$. regia L.) cultivars were moderately to highly susceptible.

Since its initial report in North America in 1967, butternut canker was subsequently reported in Canada in Quebec in 1990, in Ontario in 1991 (1), and in New Brunswick in 1997 (7), where it was thought to have been present for at least 7 years. The rapid spread of the pathogen into Canada, combined with the devastating effect of this disease, led to the butternut being designated as an Endangered Species in Canada in November 2003 (17). A recovery plan is being developed to achieve viable, self-sustaining, and broadly distributed populations within, and possibly north of, the current range of butternut in Canada (17). This will require the identification of source material to be increased and planted across the range of butternut, and the collection of seeds from various locations to conserve the native germplasm and conserve potentially resistant material. The most critical steps in the recovery program will be to ensure seed is free of the pathogen before it is distributed to recovery plan collaborators and participants for planting.

To assist in the recovery project, a rapid and reliable diagnostic method to test for the presence of $S$. clavigignenti-juglandacearum would help determine if seeds and seedlings were free of disease before planting. A molecular identification assay would be ideal. The use of a polymerase chain reaction (PCR) assay is one approach that allows for the detection of small amounts of DNA. The PCR method is a specific and sensitive assay for identification of pathogens, and is well documented in its utility $(8,14,35)$. The PCR is also reproducible for amplification of diagnostic molecular markers and could be used for identification and detection if species-specific primers were available. PCR-based diagnostic assays have been developed for several tree-infecting fungal species $(6,22,23,38)$, as well as seedinfecting fungi $(2,12,21,27,30)$. The focus of this research was to develop a process that will allow for the extraction of DNA and identification of the pathogen from plant material, including leaves, petioles, stems, trunk tissue, and seed pericarp and cotyledons. Therefore, the objective of this study was to develop a rapid, sensitive, and species-specific PCR-based diagnostic assay for the presence of $S$. clavigignentijuglandacearum in infected butternut tissues. 


\section{MATERIALS AND METHODS}

Fungal isolates. Three isolates of $S$. clavigignenti-juglandacearum, including the type-culture described by Nair et al. (16) and two isolates recovered from infected butternut in Ontario, were used for the development of the species-specific oligonucleotide primers. An additional 45 isolates of $S$. clavigignenti-juglandacearum from 12 locations (Table 1), including isolates recovered from trunk cankers, stem cankers, terminal buds, leaves, and nuts, were used for validation of the primers. Other fungi recovered from $J$. cinerea (Table 2), including those from the nut wash experiment and those from trunk, stem, leaf, and bud tissues, were included. Several species of fungi from our culture collection were also used to evaluate the specificity of the primer pair. Prior to DNA extraction, isolates were stored on potato dextrose agar (PDA) slants.

DNA sequencing and species-specific primer design. DNA was extracted using two methods. For the first method, isolates were grown in potato dextrose broth for 14 days, mycelia were collected and ground in liquid nitrogen, and DNA was extracted using the DNeasy Plant Mini Kit by Qiagen (Qiagen Inc., Valencia, CA). The second method was a modified boiling mini-prep extraction. For this method, isolates were grown on PDA for 5 to 14 days, and a sterile toothpick was used to transfer approximately $5 \mu \mathrm{g}$ of mycelia to a 1.5-ml tube containing $500 \mu \mathrm{l}$ of $4 \times \mathrm{TBE}$ buffer. Mycelia were heated at $95^{\circ} \mathrm{C}$ for 10 min. For PCR, 2 to $5 \mu \mathrm{l}$ of supernatant was added directly to the reaction. The universal primers ITS1 and ITS4 (37) were used to amplify a portion of the $18 \mathrm{~S}$ region, all of the ITS1, the 5.8S region, ITS2, and a portion of the $28 \mathrm{~S}$ region of the ribosomal DNA. A 50- $\mu$ reaction consisting of $10 \mu \mathrm{l}$ of $5 \times$ Green GoTaq reaction buffer (Promega Corp., Madison, WI), $5 \mu$ l of 25 $\mathrm{mM} \mathrm{MgCl} 2,1 \mu \mathrm{l}$ containing $10 \mathrm{mM}$ each dNTP, $0.25 \mu$ of GoTaq Taq polymerase, 5 $\mu \mathrm{l}$ each of $5-\mu \mathrm{M}$ concentration of primers ITS1 and ITS4, $2 \mu \mathrm{l}$ of DNA at a concentration of $10 \mathrm{ng} / \mu \mathrm{l}$, and $21.75 \mu \mathrm{l}$ of sterile deionized water was completed in a $0.2-\mathrm{ml}$ thin-walled microcentrifuge tube. PCR parameters were $95^{\circ} \mathrm{C}$ for $5 \mathrm{~min}$; followed by 35 cycles of $95^{\circ} \mathrm{C}$ for $1 \mathrm{~min}, 54^{\circ} \mathrm{C}$ for 1 min, $72^{\circ} \mathrm{C}$ for $1 \mathrm{~min}$; and completed with $72^{\circ} \mathrm{C}$ for $5 \mathrm{~min}$ followed by $4^{\circ} \mathrm{C}$. PCR products were purified using Qiaquick spin columns (Qiagen). For sequencing, $2 \mu \mathrm{l}$ of either ITS1 or ITS4 at 5 pmoles/ $\mu$ l was added to $2 \mu \mathrm{l}$ of purified DNA (20 ng/ $\mu \mathrm{l})$ product. Sequencing was completed at the University of Guelph Genomics Facility. Sequences were aligned and edited using BioEdit. For fungi recovered from J. cinerea, sequence data were compared with known sequences deposited in the National Center for Biotechnology Information (NCBI) nonredundant database to assist with identification.
To design primers that were specific to S. clavigignenti-juglandacearum, sequence data were used to search the NCBI database to identify species with the most similar sequence data. The eight species with the most similar internal transcribed spacer (ITS) sequence profiles were included in an alignment using ClustalW. After the alignment, a variable region within the intergenic spacer region 1 (ITS1) was identified. Using the Primer3 Plus software (34), primers were designed that spanned this variable region. This primer was named SCJF3 (5'-GTGGAGTGAGGA GCAGAC- $3^{\prime}$ ) and was used as the forward primer, and the universal primer ITS4 (37) was used as the reverse primer.

Primer specificity and sensitivity. To evaluate the sensitivity of the primers, a
DNA serial dilution ranging from $10 \mathrm{ng}$ to $10 \mathrm{fg}$ was used. DNA from all three isolates used in the alignment was evaluated at all DNA concentrations. The primers were tested for specificity on 48 isolates of S. clavigignenti-juglandacearum (Table 1) and 32 other fungal isolates (Table 2). For PCR using the SCJF3/ITS4 primer pair, a $50-\mu l$ reaction consisting of $10 \mu \mathrm{l}$ of $5 \times$ Green GoTaq reaction buffer (Promega), 5 $\mu \mathrm{l}$ of $25 \mathrm{mM} \mathrm{MgCl} 2,1 \mu \mathrm{l}$ containing 10 $\mathrm{mM}$ each dNTP, $0.25 \mu \mathrm{l}$ of GoTaq Taq polymerase, $5 \mu \mathrm{l}$ each of $5 \mathrm{pmol} / \mu \mathrm{l}$ concentration of primers SCJF3 and ITS4, $2 \mu \mathrm{l}$ of DNA at a concentration of $10 \mathrm{ng} / \mu \mathrm{l}$, and $21.75 \mu \mathrm{l}$ of sterile deionized water was carried out in a $0.2-\mathrm{ml}$ thin-walled microcentrifuge tube. PCR parameters were $95^{\circ} \mathrm{C}$ for $5 \mathrm{~min}$; followed by 35 cycles of

Table 1. Isolate designation, tissue sample, collection location, phenotype on potato dextrose agar (PDA) and date collected for Sirococcus clavigignenti-juglandacearum isolates used to evaluate the specificity of the SCJF3/ITS4 primer pair

\begin{tabular}{|c|c|c|c|c|}
\hline Isolate & Tissue & Location & Phenotype $^{\mathrm{a}}$ & Date collected \\
\hline SCJ1 & Stem & Arlington, WI, USA & $\mathrm{Dk}, \mathrm{D}$ & 1978 \\
\hline $\mathrm{SCJ} 2$ & Stem & York, ON & $\mathrm{Dk}, \mathrm{R}, \mathrm{Sp}$ & $01 / 2008$ \\
\hline SCJ3 & Stem & York, ON & Sec, R. Sp & $01 / 2008$ \\
\hline P-005 & twig & Simco Lake, ON & $\mathrm{Dk}, \mathrm{R}, \mathrm{Sp}$ & $7 / 18 / 2008$ \\
\hline WB22 & Stem & Cambridge, ON & $\mathrm{L}, \mathrm{Sp}, \mathrm{R}$ & $3 / 25 / 2009$ \\
\hline GA1-1 & Stem & Guelph, ON & $\mathrm{Dk}, \mathrm{R}, \mathrm{Sp}$ & $4 / 14 / 2009$ \\
\hline GA5-1 & Stem & Guelph, ON & $\mathrm{Dk}, \mathrm{R}, \mathrm{Sp}$ & $4 / 14 / 2009$ \\
\hline Bud 2-3 & Terminal bud & Guelph, ON & $\mathrm{L}, \mathrm{R}, \mathrm{Sp}$ & $4 / 14 / 2009$ \\
\hline Bud 2-2 & Terminal bud & Guelph, ON & $\mathrm{Dk}, \mathrm{R}, \mathrm{Sp}$ & $4 / 14 / 2009$ \\
\hline WB2-4 & Stem & Cambridge, ON & $\mathrm{L}, \mathrm{Sp}, \mathrm{R}$ & $3 / 25 / 2009$ \\
\hline Bud 2-1 & Terminal bud & Guelph, ON & $\mathrm{Dk}, \mathrm{R}, \mathrm{Sp}$ & $4 / 14 / 2009$ \\
\hline GA $2-3$ & Stem & Guelph, ON & Dk, D & $4 / 14 / 2009$ \\
\hline 259L-LB11 & Lateral bud & Guelph, ON & $\mathrm{Dk}, \mathrm{D}$ & $4 / 25 / 2009$ \\
\hline B6L-LB23 & Lateral bud & Guelph, ON & $\mathrm{Dk}, \mathrm{D}$ & $4 / 25 / 2009$ \\
\hline B6L-TB 11 & Terminal bud & Guelph, ON & Sec, $R, S p$ & $4 / 25 / 2009$ \\
\hline B6L-TB12 & Terminal bud & Guelph, ON & $\mathrm{Dk}, \mathrm{D}$ & $4 / 25 / 2009$ \\
\hline WB1-2 & Terminal bud & Cambridge, ON & Dk, D & $5 / 5 / 2009$ \\
\hline WB1-28 & Lateral bud & Cambridge, ON & $\mathrm{Dk}, \mathrm{R}, \mathrm{Sp}$ & $5 / 5 / 2009$ \\
\hline WB1-8 & Lateral bud & Cambridge, ON & $\mathrm{L}, \mathrm{Sp}, \mathrm{R}$ & $5 / 5 / 2009$ \\
\hline WB4-16 & Bud scar & Cambridge, ON & $\mathrm{L}, \mathrm{Sp}, \mathrm{R}$ & $5 / 5 / 2009$ \\
\hline WB4-8 & Lateral bud & Cambridge, ON & Sec, R, Sp & $5 / 5 / 2009$ \\
\hline WB-32 & Outer pericarp & Cambridge, ON & $\mathrm{Dk}, \mathrm{D}$ & $7 / 8 / 2009$ \\
\hline WB-34 & Seed cotyledon & Cambridge, ON & Sec, R, Sp & $7 / 8 / 2009$ \\
\hline WB-36 & Outer pericarp & Cambridge, ON & $\mathrm{Dk}, \mathrm{R}, \mathrm{Sp}$ & $7 / 8 / 2009$ \\
\hline WB-37 & Outer pericarp & Cambridge, ON & $\mathrm{L}, \mathrm{Sp}, \mathrm{R}$ & $7 / 8 / 2009$ \\
\hline $70-13$ & New stem & Arkell, ON & $\mathrm{Dk}, \mathrm{R}, \mathrm{Sp}$ & $6 / 15 / 2009$ \\
\hline $70-16$ & New stem & Arkell, ON & $\mathrm{Dk}, \mathrm{D}$ & $6 / 15 / 2009$ \\
\hline $70-17$ & Stem canker & Arkell, ON & Dk, D & $6 / 15 / 2009$ \\
\hline $70-18$ & Stem canker & Arkell, ON & $\mathrm{Dk}, \mathrm{R}, \mathrm{Sp}$ & $6 / 15 / 2009$ \\
\hline $70-19$ & Leaf lesion & Arkell, ON & Dk, D & $6 / 15 / 2009$ \\
\hline $70-20$ & Leaf lesion & Arkell, ON & $\mathrm{Dk}, \mathrm{R}, \mathrm{Sp}$ & $6 / 15 / 2009$ \\
\hline $70-21$ & Leaf lesion & Arkell, ON & Dk, D & $6 / 15 / 2009$ \\
\hline 70-BW1 & Black walnut & Arkell, ON & $\mathrm{Dk}, \mathrm{D}$ & $6 / 15 / 2009$ \\
\hline P12-2-1 & Terminal bud & Big Rideau Lake, ON & Dk, D & $6 / 28 / 2009$ \\
\hline P12-2-5 & Leaf lesion & Big Rideau Lake, ON & $\mathrm{Dk}, \mathrm{R}, \mathrm{Sp}$ & $6 / 29 / 2009$ \\
\hline P12-3-5 & Terminal bud & Big Rideau Lake, ON & Dk, D & $6 / 30 / 2009$ \\
\hline P-003 & Twig & Simco Lake, ON & $\mathrm{Dk}, \mathrm{R}, \mathrm{Sp}$ & $7 / 17 / 2008$ \\
\hline P-008 & Twig & Simco Lake, ON & $\mathrm{Dk}, \mathrm{D}$ & $7 / 30 / 2008$ \\
\hline P-010 & Twig & Simco Lake, ON & Dk, D & $8 / 3 / 2008$ \\
\hline $\mathrm{P}-013$ & Twig & Guelph Lake, ON & $\mathrm{Dk}, \mathrm{D}$ & $8 / 8 / 2008$ \\
\hline P-017 & Twig & Conestoga Lake, ON & $\mathrm{Dk}, \mathrm{D}$ & $8 / 14 / 2008$ \\
\hline P-019 & Twig & Hockley Valley PNR, ON & $\mathrm{Dk}, \mathrm{D}$ & $8 / 22 / 2008$ \\
\hline P-029 & Twig & Simco Lake, ON & $\mathrm{L}, \mathrm{Sp}, \mathrm{R}$ & $8 / 14 / 2008$ \\
\hline P-034 & Twig & Bradford, ON & Dk, D & $8 / 26 / 2008$ \\
\hline P-037 & Twig & Brockville, ON & $\mathrm{Dk}, \mathrm{D}$ & $8 / 28 / 2008$ \\
\hline P-043 & Twig & Charleston Lake, ON & $\mathrm{Dk}, \mathrm{D}$ & $9 / 11 / 2008$ \\
\hline P-045 & Twig & Big Rideau Lake, ON & $\mathrm{Dk}, \mathrm{D}$ & $9 / 16 / 2008$ \\
\hline P-046 & Twig & Big Rideau Lake, ON & $\mathrm{Dk}, \mathrm{D}$ & $9 / 17 / 2008$ \\
\hline
\end{tabular}

a Abbreviations for phenotypes refer to appearance of mycelia on PDA and are as follows: Dk = dark, $\mathrm{L}=$ light, $\mathrm{Sec}=$ sectored, $\mathrm{D}=$ diffuse, $\mathrm{R}=$ rings, $\mathrm{Sp}=$ sporulating. 
$95^{\circ} \mathrm{C}$ for $30 \mathrm{~s}, 55^{\circ} \mathrm{C}$ for $30 \mathrm{~s}, 72^{\circ} \mathrm{C}$ for 1 min; and completed with $72^{\circ} \mathrm{C}$ for $5 \mathrm{~min}$ followed by $4^{\circ} \mathrm{C}$. To rule out a possible inhibition of the PCR reaction or lack of template DNA, universal primers ITS1 and ITS4, which amplify the intergenic spacer region, were used to amplify the fungal DNA of the respective fungi recovered from butternut tissue and culture collections.

Infected plant tissues were also used to evaluate the primers. Bud, leaf, petiole, stem, and trunk tissues with visible symptoms of infection (Fig. 1) were sampled from butternut trees. To confirm the presence of $S$. clavigignenti-juglandacearum, a portion of the affected area was surface sterilized and cultured on acidified PDA. DNA was extracted from these tissues using the MoBio Power Soil DNA extraction kit (Mo Bio Laboratories Inc., Carlsbad, CA). To improve the efficiency of DNA recovery after plant tissue was added to the first bead tube of the MoBio kit, tubes were incubated at $75^{\circ} \mathrm{C}$ for $15 \mathrm{~min}$ prior to the vortexing step. The PCR reaction of DNA extracted from infected plant tissue was the same as mentioned previ-

Table 2. List of fungal isolates ${ }^{\mathrm{a}}$ used to evaluate the specificity of the SCJF3/ITS4 primer pair

\begin{tabular}{|c|c|c|c|}
\hline Isolate & Genus & Species & Source \\
\hline BE11 & Alternaria & alternata & J. cinerea endocarp \\
\hline N60C2 & Alternaria & alternata & J. cinerea nut surface \\
\hline BC21 & Aspergillus & tubigensis & J. cinerea cotyledon \\
\hline N30A3 & Aureobasidium & pullulans & J. cinerea nut surface \\
\hline W15B4 & Dothioraceae & sp. & J. cinerea nut surface \\
\hline P12-1-7 & Epicoccum & nigrum & J. cinerea branch \\
\hline WB-35 & Epicoccum & sp. & J. cinerea branch \\
\hline BE33 & Fusarium & oxysporum & J. cinerea branch \\
\hline WB-36 & Fusarium & graminearum & J. cinerea branch \\
\hline WB26 & Fusarium & lateritium & J. cinerea branch \\
\hline BE21 & Fusarium & equiseti & J. cinerea endocarp \\
\hline N30B1 & Fusarium & proliferatum & J. cinerea nut surface \\
\hline N60B4 & Fusarium & graminearum & J. cinerea nut surface \\
\hline W30C1 & Fusarium & solani & J. cinerea nut surface \\
\hline W60C3 & Fusarium & proliferatum & J. cinerea nut surface \\
\hline W30B3 & Geotricum & sp. & J. cinerea nut surface \\
\hline P12-3-2 & Gnomonia & leptostyla & J. cinerea branch \\
\hline W1 & Melanconis & sp. & J. cinerea branch \\
\hline $70-12$ & Melanconis & juglandis & J. cinerea branch \\
\hline W11 & Nectria & sp. & J. cinerea branch \\
\hline N30B4 & Penicillium & glandicola & J. cinerea nut surface \\
\hline W30B2 & Penicillium & spp. & J. cinerea nut surface \\
\hline W14 & Phoma & glomerata & J. cinerea branch \\
\hline W16 & Phoma & sp. & J. cinerea branch \\
\hline P12-1-1 & Phoma & sp. & J. cinerea branch \\
\hline N60B3 & Plectosphaerella & cucumeria & J. cinerea nut surface \\
\hline F1M3 & Botryosphaeria & obtusa & Culture collection \\
\hline \multirow[t]{3}{*}{$115-2$} & Cryphonectria & parasitica & Culture collection \\
\hline & Fusarium & graminearum & Culture collection \\
\hline & Fusarium & verticillioides & Culture collection \\
\hline Win80 & Ophiostoma & ulmi & Culture collection \\
\hline SS357 & Sclerotinia & sclerotiorum & Culture collection \\
\hline
\end{tabular}

${ }^{a}$ Isolates were identified to genus or species level using both morphological traits and sequence data from the ITS1, 5.8S, and ITS2 regions of the ribosomal DNA.
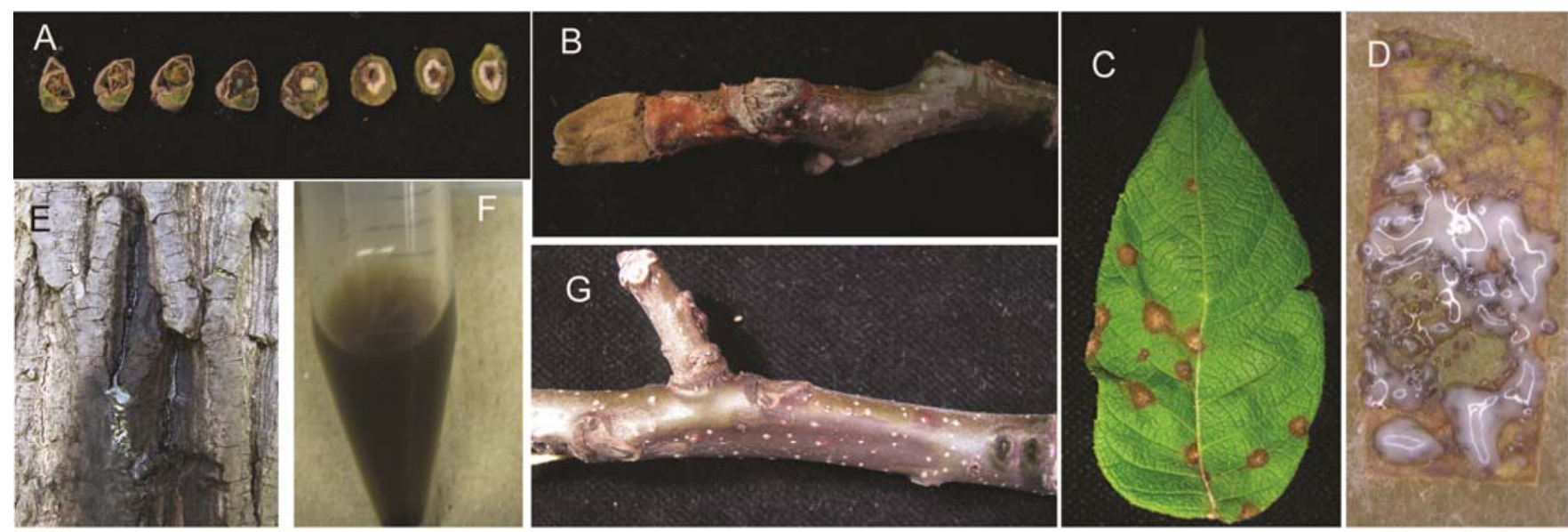

Fig. 1. Symptoms of Sirococcus clavigignenti-juglandacearum infection on butternut (Juglans cinerea). A, Terminal bud cross-section; B, bud dieback; C, leaf; D, leaf with production of conidia from lesions in culture; $\mathbf{E}$, trunk canker; $\mathbf{F}$, liquid discharge from cankers; and $\mathbf{G}$, stem. 
1). Colony morphology differed on PDA. Four distinct phenotypes were observed: cultures were (I) dark, with diffuse mycelia, and without rings; (ii) cultures were dark, with diffuse mycelia, rings, and sporulating; (iii) cultures had light-colored mycelia, rings, and sporulating; or (iv) cultures were sectored (both dark and light mycelia), with rings, and sporulating (Fig. 2 ). There was no difference in the ITS sequence among any of the four phenotypes observed.

DNA sequencing and species-specific primer design. Oligonucleotide primers were developed based on the ITS1 and ITS2 regions of isolates SCJ1 (ATCC 3662), which is the type culture, and SCJ2 and SCJ3, which were recovered from $J$. cinerea in Ontario. The sequence data for SCJ1, SCJ2, and SCJ3 were deposited in the GenBank database under accession numbers GU183863, GU183864, and GU183865, respectively. The ITS region was identical for all three isolates sequenced. The species found to have the most similar sequence data were from the genus Gnomonia, and were recently reclassified to the genus Ophiognomonia (28). There was little sequence similarity with other species of Sirococcus. A variable region within ITS1 was identified as an optimal position for designing a forward primer specific to $S$. clavigignentijuglandacearum. The universal primer ITS4 (37) was used as the reverse primer.

Primer specificity and sensitivity. The SCJF3/ITS4 primer pair amplified a putative 467-bp amplicon in each of the 48 isolates, which included the four different phenotypes, tested in this study (Fig. 3). The primers did not amplify DNA from the other 32 fungal isolates tested, including 26 isolates recovered from various infected butternut tissues (Table 2). In addition, the boiling mini-prep extraction method was successful at extracting DNA from mycelia and spores of $S$. clavigignenti-juglandacearum that could be used in PCR reactions using the specific primers (Fig. 3B). DNA extracted from isolates of $S$. clavigignenti-juglandacearum using the Qiagen DNeasy kit had a concentration ranging from 20 to $50 \mathrm{ng} / \mu \mathrm{l}$. DNA concentrations were measured using a Nano-drop spectrophotometer (Thermo Fisher Scientific Inc., Waltham, MA). It was this DNA that was used in the serial dilutions to test the sensitivity of the SCJF3/ITS4 primer pair. The primers were able to amplify $S$. clavigignenti-juglandacearum DNA at concentrations as low as $10 \mathrm{pg}$, and a faint band was often seen with as little as $1 \mathrm{pg}$ of starting DNA.

Detection of S. clavigignenti-juglandacearum in butternut tissue and nut-wash fluid. The primers designed in this study were also used to amplify DNA of $S$. clavigignenti-juglandacearum directly from infected tissue from butternut trees. In all, 33 pieces of plant tissue were sampled

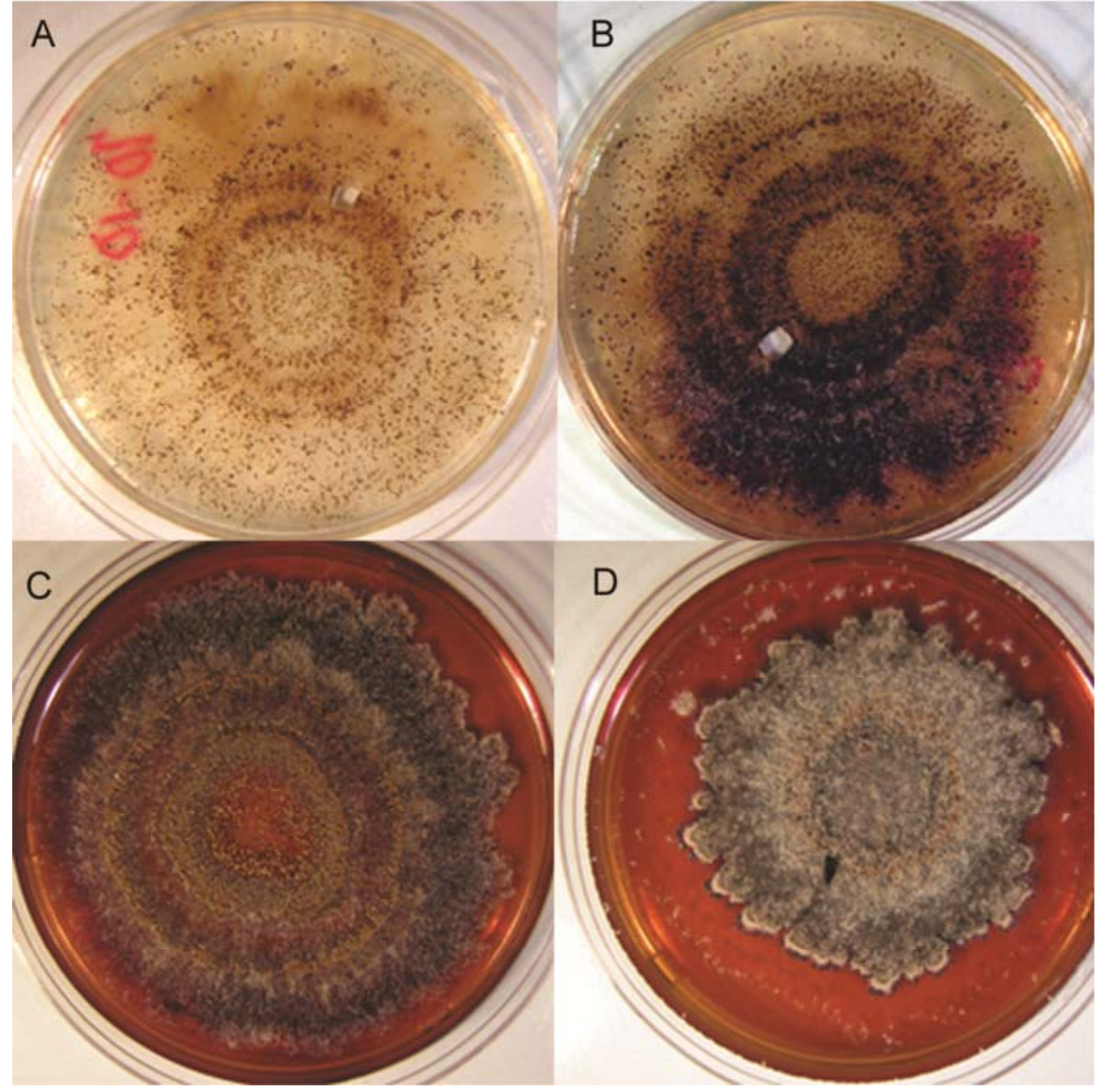

Fig. 2. The four phenotypes of Sirococcus clavigignenti-juglandacearum observed on potato dextrose agar. Phenotypes included cultures with $\mathbf{A}$, light mycelia with rings and sporulation (L, R, Sp), B, sectored cultures with rings and sporulation ( $\mathrm{Sec}, \mathrm{R}, \mathrm{Sp}$ ), C, dark mycelia with rings and sporulation and dark pigmentation of the agar (Dk, R, Sp), and $\mathbf{D}$, dark and diffuse mycelia with no rings and dark pigmentation of the agar (Dk, D).
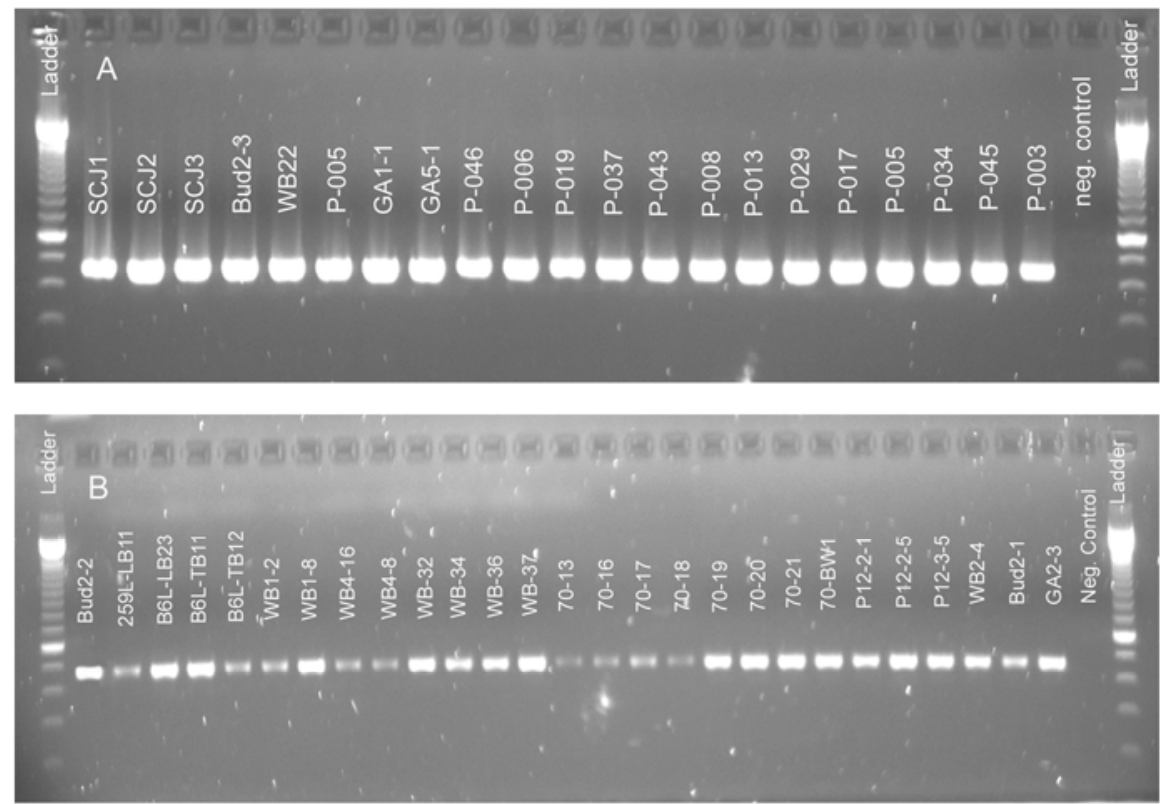

Fig. 3. Polymerase chain reaction (PCR) product amplified from the internal transcribed spacer region of rDNA, using the SCJF3/ITS4 primer pair, from 48 isolates of Sirococcus clavigignentijuglandacearum collected in Ontario. DNA was extracted using two methods: A, the DNeasy Plant Mini Kit by Qiagen or B, a modified boiling mini-prep extraction method, for which a sterile toothpick was used to transfer approximately $5 \mu \mathrm{g}$ of mycelia to a $1.5-\mathrm{ml}$ tube containing $500 \mu \mathrm{l}$ of $4 \times \mathrm{TBE}$ buffer, and was denatured at $95^{\circ} \mathrm{C}$ for $10 \mathrm{~min}$. For PCR, 2 to $5 \mu \mathrm{l}$ of the supernatant was added directly to the reaction. A negative control and 100-bp ladder are shown. 
from three locations in southern Ontario (Table 3). Amplification of pathogen DNA was successfully detected in 22 of the 33 pieces of plant tissue including tissue from black walnut (J. nigra) and heartnut ( $J$. ailantifolia Carr. var. cordiformis). The presence of $S$. clavigignenti-juglandacearum was confirmed from infected buds, stem tissue lesions, petiole lesions, leaf lesion, seed outer pericarp, seed cotyledons, trunk cankers, and exudate from trunk cankers using the SCJF3/ITS4 primer pair (Table 3, Fig. 4). The primers amplified DNA from asymptomatic terminal buds and seed sampled from butternut, matic stems and leaves (Table 3). $S$. clavigignenti-juglandacearum was also successfully cultured onto acidified PDA from infected buds, stems, petioles, leaves, seeds, and trunk cankers. However, as the season progressed into July and August, it became increasingly difficult to culture the fungus from lesions attributed to $S$. clavigignenti-juglandacearum infection, but the PCR diagnostic assay continued to detect the presence of the pathogen in infected tissue. Attempts to isolate the pathogen from trunk canker exudates were inhibited by the presence of large amounts of bacteria. However, the molecular diagnostic was able to detect the pathogen in the presence of the bacteria in the exudate.

In addition to testing the primers for their ability to detect $S$. clavigignentijuglandacearum DNA in infected plant tissue, the primers were also evaluated for their efficacy in detecting the pathogen during the dehusking process. The pathogen was not detected from seeds that had but did not amplify DNA from asympto-

already been dehusked and used in the nutwash simulations. However, the presence of $S$. clavigignenti-juglandacearum was detected in the laboratory simulation of the dehusking process via spiking nutwash water and subsequently extracting DNA from these samples. The detection of $S$. clavigignenti-juglandacearum conidia by the SCJF3/ITS4 primer pair was similar when DNA was extracted from conidia suspended in water or when conidia were added to the nut-wash process, indicating that a sufficient number of spores were not lost in the centrifugation steps to decrease total DNA yield. The $S$. clavigignenti-juglandacearum specific primers were able to detect the presence of the pathogen at a concentration of $1 \times$ $10^{3}$ spores in laboratory nut-wash simulations. This result was similar when DNA was extracted from spores suspended in $\mathrm{H}_{2} \mathrm{O}$.

\section{DISCUSSION}

In the present study, a PCR-based diagnostic assay was developed to detect $S$. clavigignenti-juglandacearum in infected plant tissue and from spores during a nutwash process, using pathogen-specific primers derived from the ITS region of the rDNA of S. clavigignenti-juglandacearum. Nuclear ribosomal DNA continues to be an attractive source for designing speciesspecific primers for the detection of the pathogen of interest. This is the result of several factors, the first being that a large and growing database of ITS sequences from a variety of fungi is readily available from GenBank. Secondly, the ITS region is highly conserved within individual species,
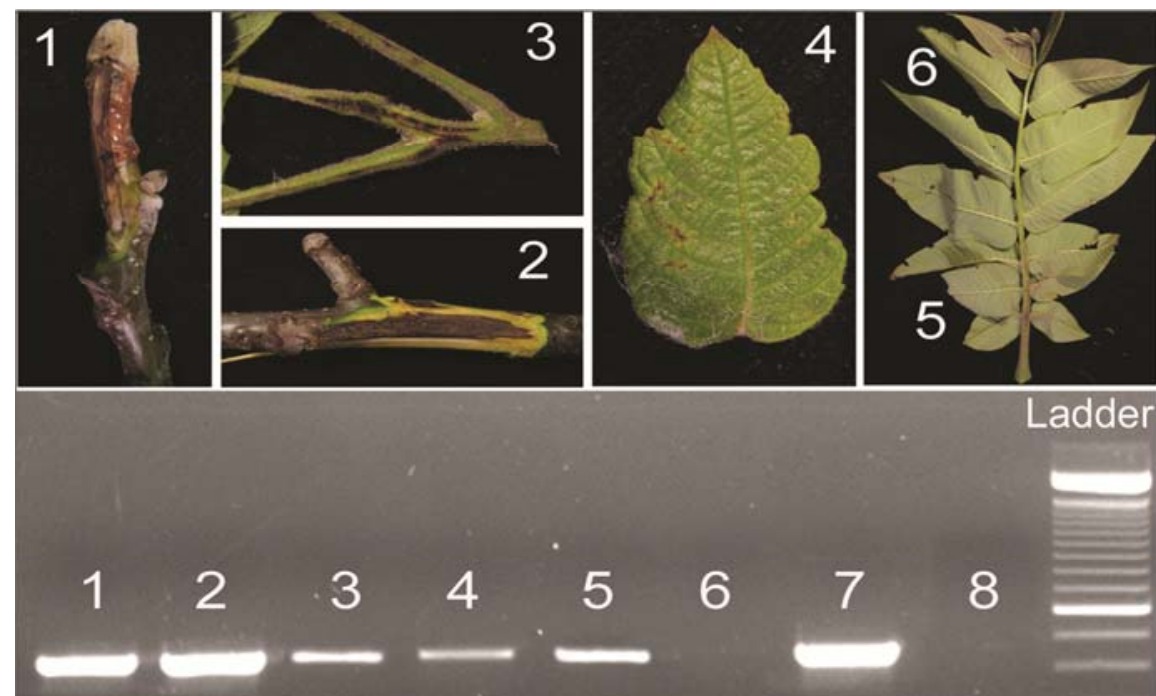

Fig. 4. Polymerase chain reaction of DNA extracted from symptomatic lesions on 1 , terminal bud; 2 branch; 3 , petiole; 4 , leaf; and 5, petiole tissue; and from 6 , asymptomatic petiole tissue using the SCJF3/ITS4 primer pair. Lanes 7 and 8 are the positive (Sirococcus clavigignenti-juglandacearum DNA) and negative (no DNA) controls, respectively. Numbers in the plant tissue images correspond with lane numbers in the gel image. The gel is $1.5 \%$ agarose with a 100-bp ladder shown. yet variable among species $(4,10,13)$. This study found that DNA sequences of the eight isolates of S. clavigignenti-juglandacearum were identical over a 595-bp region spanning from the $3^{\prime}$ end of the $18 \mathrm{~S}$ rRNA gene to the $5^{\prime}$ end of the 28S rRNA gene. The lack of variation in the ITS region of the eight isolates is consistent with the view that the ITS region is conserved within species (36) and that there is little or no genotypic variation among isolates of $S$. clavigignenti-juglandacearum in North America (3).

Symptoms of infection by S. clavigignenti-juglandacearum on butternut trees include discrete, elliptical to fusiform cankers involving the bark and wood of twigs, branches, stems, and even exposed buttress roots (16). Young cankers commonly originate at leaf scars, buds, lenticels, and bark wounds, including insect wounds and natural bark cracks (16). These symptoms plus trunk cankers and developing cankers on younger branches are the basis for visual disease assessment. Therefore, in sampling for PCR-based detection, plant tissue from all areas of the host were sampled to ensure that DNA extraction and PCR amplification for the detection of the pathogen would be successful for all tissues. PCR amplification of fungal DNA isolated from several types of plant tissue allowed for the amplification of presumably small amounts of biomass of $S$. clavigignentijuglandacearum. The effects of inhibitors on the PCR reaction commonly found in the DNA extracts from plant materials were overcome by using the MoBio PowerSoil DNA extraction kit, which is designed for isolation of high-quality DNA from environmental samples. There was even an observable difference in band intensity among the different plant tissue samples (Fig. 4). This was likely due to the variable amounts of fungal biomass in the individual samples.

For a diagnostic assay to be successfully employed, it requires a high level of specificity and sensitivity. The specificity of the SCJF3/ITS4 primers have proven to be reliable, as DNA from several fungi commonly found on butternut were not successfully amplified, including the closely related fungi Ophiognomonia leptostyla (Fr.) Sogonov and Melanconis juglandis (Ellis \& Everh.) A.H. Graves. In addition, the primer pair successfully amplified the target region of 48 isolates of $S$. clavigignenti-juglandacearum from 11 locations in Ontario. In regards to sensitivity, the assay was able to detect as little as $100 \mathrm{fg}$ of DNA, and the assay was able to detect as few as 1,000 spores of $S$. clavigignenti-juglandacearum in a simulated nut-wash process. The assay was also able to consistently detect the pathogen in a variety of infected tissues, including leaves, buds, petioles, stems, seed pericarp and cotyledon, trunk tissue, exudate from trunk cankers of butternut, as well as 
leaves of $J$. nigra, and stems and buds of $J$. ailantifolia var. cordiformis. Therefore, the diagnostic assay developed in this study using the SCJF3/ITS4 primer pair satisfies both the specificity and sensitivity requirements for diagnostic applications.

The diagnostic assay developed in this study could prove to be valuable in the early detection of the pathogen on seed, nursery stock, and scionwood. However, each of these has its limitations. Because butternut seed is generally in small supply, destructive testing to access the cotyledon is generally not an option. Therefore, sampling the pericarp prior to dehusking, and the rinse water during the dehusking process may be viable alternatives. In addition, seeds that fail to germinate and symptomatic seedlings can be tested to determine if the pathogen was responsible for the failed germination or the visible symptoms, respectively. Where the diagnostic assay may prove to be the most valuable is in the testing of nursery stock and scionwood before it is transferred to a new location to ensure that it is disease free, or to ensure that diseased individuals are removed from production to prevent further spread of the pathogen.

Although there is much interest in conserving butternut and managing butternut canker, most of the research has been focused on finding host resistance $(15,19$, 20,25,26). However, there are still many unanswered questions regarding the epidemiology of this disease, primarily the long-distance spread and potential for seed transmission of the pathogen. Some type of vector is suspected for this pathogen, primarily because of the geographically scattered nature of butternut and the rapid spread of the pathogen throughout North America. The most likely sources of longdistance spread are insect vectors $(5,11,29)$, seed transmission (9), and/or wind-blown spores $(31,32)$. The development of a rapid diagnostic assay for the presence of $S$. clavigignenti-juglandacearum in this study will enable future epidemiological studies to test various sources of pathogen spread, such as seeds, insects, alternative hosts, or wind-blown spores.

Table 3. Tissue samples, collection location, date collected, and symptoms present on different plant tissues used to evaluate the Sirococcus clavigignenti-juglandacearum molecular diagnostic assay $^{\mathrm{a}}$

\begin{tabular}{|c|c|c|c|c|}
\hline Plant tissue & Location & Date & Symptoms & $\begin{array}{l}\text { Presence } \\
\text { of isolate }^{b}\end{array}$ \\
\hline J. cinerea current year stem & Guelph, ON & $6 / 12 / 2009$ & Dieback & + \\
\hline J. cinerea current year stem & Guelph, ON & $6 / 12 / 2009$ & Reddish lesion & + \\
\hline J. cinerea current year stem & Guelph, ON & $6 / 12 / 2009$ & No & - \\
\hline J. cinerea stem canker & Guelph, ON & $6 / 12 / 2009$ & Canker & + \\
\hline$J$. cinerea catkin & Guelph, ON & $6 / 12 / 2009$ & Frost damage & - \\
\hline J. cinerea trunk canker & Guelph, ON & $6 / 12 / 2009$ & Canker & + \\
\hline J. cinerea leaf & Guelph, ON & $6 / 12 / 2009$ & Fungal lesions & - \\
\hline$J$. cinerea seed pericarp & Cambridge, ON & $7 / 9 / 2009$ & No & + \\
\hline J. cinerea seed pericarp & Cambridge, ON & 7/9/2009 & No & - \\
\hline J. cinerea seed cotyledon & Cambridge, ON & 7/9/2009 & No & + \\
\hline J. cinerea terminal bud & Cambridge, ON & $7 / 9 / 2009$ & Dieback & + \\
\hline J. cinerea terminal bud & Cambridge, ON & 7/9/2009 & No & + \\
\hline J. cinerea current year stem & Cambridge, ON & 7/9/2009 & Dieback & + \\
\hline J. nigra seed pericarp & Cambridge, ON & 7/9/2009 & No & - \\
\hline J. nigra petiole tissue & Cambridge, ON & $7 / 9 / 2009$ & Fungal lesion & + \\
\hline J. nigra petiole tissue & Cambridge, ON & $7 / 9 / 2009$ & Fungal lesion & _- \\
\hline$J$ cinerea trunk canker exudate & Guelph, ON & $7 / 16 / 2009$ & Canker ooze & + \\
\hline J. cinerea trunk canker exudate & Guelph, ON & $7 / 16 / 2009$ & Canker ooze & + \\
\hline$J$. cinerea trunk canker & Guelph, ON & $7 / 16 / 2009$ & Canker & + \\
\hline J. cinerea trunk canker & Guelph, ON & $7 / 16 / 2009$ & Canker & + \\
\hline $\begin{array}{l}\text { J. ailantifolia var. cordiformis } \\
\text { terminal bud }\end{array}$ & Guelph, ON & $7 / 16 / 2009$ & Dieback & + \\
\hline $\begin{array}{l}\text { J. ailantifolia var. cordiformis } \\
\text { terminal bud }\end{array}$ & Guelph, ON & $7 / 16 / 2009$ & No & + \\
\hline $\begin{array}{l}\text { J. ailantifolia var. cordiformis } \\
\text { stem }\end{array}$ & Guelph, ON & $7 / 16 / 2009$ & Dieback & - \\
\hline J. nigra leaf & Aylmer, ON & $8 / 11 / 2009$ & Fungal lesion & _- \\
\hline$J$. nigra leaf & Aylmer, ON & $8 / 11 / 2009$ & Fungal lesion & - \\
\hline J. nigra petiole & Aylmer, ON & $8 / 11 / 2009$ & Fungal lesion & + \\
\hline J. nigra petiole & Aylmer, ON & $8 / 11 / 2009$ & Fungal lesion & + \\
\hline J. cinerea leaf & Guelph, ON & $8 / 27 / 2009$ & Fungal lesion & + \\
\hline$J$. cinerea leaf & Guelph, ON & $8 / 27 / 2009$ & Fungal lesion & + \\
\hline$J$. cinerea petiole & Guelph, ON & $8 / 27 / 2009$ & No & - \\
\hline J. cinerea petiole & Guelph, ON & $8 / 27 / 2009$ & Fungal lesion & + \\
\hline J. cinerea terminal bud & Guelph, ON & $8 / 27 / 2009$ & No & - \\
\hline J. cinerea terminal bud & Guelph, ON & $8 / 27 / 2009$ & Dieback & + \\
\hline
\end{tabular}

${ }^{a}$ Symptomatic and asymptomatic tissues were collected from butternut (Juglans cinerea), black walnut (J. nigra), and heartnut (J. ailantifolia var. cordiformis).

${ }^{\mathrm{b}}$ The $(+)$ and (-) symbols represent the positive amplification of $S$. clavigignenti-juglandacearum DNA using the SCJF3/ITS4 primer pair and the failure to amplify S. clavigignenti-juglandacearum DNA, respectively.

ACKNOWLEDGMENTS

We thank Richard Wilson, Ontario Ministry of Natural Resources (OMNR), for assistance in locating butternut seeds and infected trees in Ontario, OMNR for funding of the project, the R. J. Hilton Centre of the University of Guelph Arboretum and the RARE Charitable Research Reserve for access to butternut trees.

\section{LITERATURE CITED}

1. Davis, C. N., Myren, D. T., and Czerwinski, E. J. 1992. First report of butternut canker in Ontario. Plant Dis. 76:972.

2. Doohan, F. M., Parry, D. W., Jenkinson, P., and Nicholson, P. 1998. The use of species specific PCR based assays to analyse Fusarium ear blight of wheat. Plant Pathol. 47:197-205.

3. Furnier, G. R., Stolz, A. M., Mustaphi, R. M., and Ostry, M. E. 1999. Genetic evidence that butternut canker was recently introduced into North America. Can. J. Bot. 77:783-785.

4. Goodwin, P. H., Hsiang, T., Xue, B. G., and Liu, H. W. 1995. Differentiation of Gaeumanomyces graminis from other turf-grass fungi by amplification with primers from ribosomal internal transcribed spacers. Plant Pathol. 44:384-391.

5. Halik, S., and Bergdahl, D. R. 2002. Potential beetle vectors of Sirococcus clavigignentijuglandacearum on butternut. Plant Dis. 86:521-527.

6. Hamelin, R. C., Bourassa, N., Rail, J., Dusabenyagasani, M., Jacobi, V., and Laflamme, G 2000. PCR detection of Gremmeniella abiet ina, the causal agent of Scleroderris canker of pine. Mycol. Res. 104:527-532.

7. Harrison, K. J., Hurley, J. E., and Ostry, M. E. 1998. First report of butternut canker caused by Sirococcus clavigignenti-juglandacearum in New Brunswick, Canada. Plant Dis. $82: 1282$.

8. Henson, J. M., and French, R. 1993. The polymerase chain reaction and plant disease diagnosis. Annu. Rev. Phytopathol. 31:81-109.

9. Innes, L., and Rainville, A. 1996. Distribution and detection of Sirococcus clavigignentijuglandacearum in Quebec. Phytoprotection 77:75-78.

10. Johanson, A., and Jeger, M. 1993. Use of PCR detection of Mycosphaerella fijiensis and $M$. musicola, the causal agents of Sigatoka leaf spots in banana and plantain. Mycol. Res. 97:670-674.

11. Katovich, S. A., and Ostry, M. E. 1998. Insects associated with butternut and butternut canker in Minnesota and Wisconsin. Great Lakes Entomol. 31:97-108.

12. Lee, H. K., Tewari, J. P., and Turkington, T. K. 2001. A PCR-based assay to detect Rhynchosporium secalis in barley seed. Plant Dis. 85:220-225.

13. Lovic, B. R., Martyn, R. D., and Miller, M. E. 1995. Sequence analysis of the ITS regions of rDNA in Monosporascus spp. to evaluate its potential for PCR-mediated detection. Phytopathology 85:655-661.

14. McCartney, H. A., Foster, S. J., Fraaije, B. A., and Ward, E. 2003. Molecular diagnostics for fungal plant pathogens. Pest Manag. Sci. 59:129-142.

15. Michler, C. H., Pijut, P. M., Jacobs, D. F., Meilan, R., Woeste, K. E., and Ostry, M. E. 2006. Improving disease resistance of butternut (Juglans cinerea), a threatened fine hardwood: A case for single-tree selection through genetic improvement and deployment. Tree Physiol. 26:121-128.

16. Nair, V. M. G., Kostichka, C. J., and Kuntz, J. E. 1979. Sirococcus clavigignenti-juglandacearum: An undescribed species causing canker on butternut. Mycologia 71:641-646.

17. Neilson, C., Cherry, M., Boysen, B., Hopkin, A., McLaughlin, J., and Beardmore, T. 2003. COSEWIC status report on the butternut Jug- 
lans cinerea in Canada. Pages 1-32 in: COSEWIC Assessment and Status Report on the Butternut Juglans cinerea in Canada. Committee on the Status of Endangered Wildlife in Canada, Ottawa.

18. Ostry, M. E., and Moore, M. 2007. Natural and experimental host range of Sirococcus clavigignenti-juglandacearum. Plant Dis. 91:581584.

19. Ostry, M. E., and Moore, M. 2008. Response of butternut selections to inoculation with $\mathrm{Si}$ rococcus clavigignenti-juglandacearum. Plant Dis. 92:1336-1338.

20. Ostry, M. E., and Woeste, K. 2004. Spread of butternut canker in North America, host range, evidence of resistance within butternut populations and conservation genetics. Pages 114-120 in: Black Walnut in a New Century. Proc. Walnut Council Res. Sympos., 6th. C. H. Michler, P. M. Pijut, J. Van Sambeek, M. Coggeshall, J. Seifert, K. Woeste, and R. Overton. eds. Gen. Tech. Rep. NC-243, U.S. Dep. Agric. For. Serv. North Central For. Exp. Stn., St. Paul, MN.

21. Parry, D. W., and Nicholson, P. 1996. Development of a PCR assay to detect Fusarium poae in wheat. Plant Pathol. 45:383-391.

22. Piskur, B., Ogris, N., and Jurc, D. 2007. Species-specific primers for Eutypella parasitica, the causal agent of Eutypella canker of maple. Plant Dis. 91:1579-1584.

23. Ramsfield, R. D., Dobbie, K., Dick, M. A., and Ball, R. D. 2008. Polymerase chain reactionbased detection of Fusarium circinatum, the causal agent of pitch canker disease. Mol. Ecol. Resour. 8:1270-1273.

24. Renlund, D. W. 1971. Forest pest conditions in Wisconsin. Annu. Rep. Wisconsin Department of Natural Resources, Madison, WI.

25. Ross-Davis, A., Huang, Z. L., McKenna, J., Ostry, M., and Woeste, K. 2008. Morphological and molecular methods to identify butternut (Juglans cinerea) and butternut hybrids: Relevance to butternut conservation. Tree Physiol. 28:1127-1133.

26. Ross-Davis, A., Ostry, M., and Woeste, K. E. 2008. Genetic diversity of butternut (Juglans cinerea) and implications for conservation. Can. J. For. Res. 38:899-907.

27. Smith, O. P., Peterson, G. L., Beck, R. J., Schaad, N. W., and Bonde, M. R. 1996. Development of a PCR-based method for identification of Tilletia indica, causal agent of Karnal bunt of wheat. Phytopathology 86:115-122.

28. Sogonov, M. V., Castlebury, L. A., Rossman, A. Y., Meija, L. C., and White, J. F. 2008. Leaf-inhabiting genera of the Gnomoniaceae, Diapothathales. Stud. Mycol. 62:1-79.

29. Stewart, J. E., Halik, S., and Bergdahl, D. R. 2004. Viability of Sirococcus clavigignentijuglandacearum conidia on exoskeletons of three coleopteran species. Plant Dis. 88:10851091.

30. Taylor, J. L. 1993. A simple, sensitive, and rapid method for detecting seed contaminated with highly virulent Leptosphaeria maculans. Appl. Environ. Microbiol. 59:3681-3685.
31. Tisserat, N., and Kuntz, J. E. 1983. Dispersal gradients of conidia of the butternut canker fungus in a forest during rain. Can. J. For. Res. 13:1139-1144.

32. Tisserat, N., and Kuntz, J. E. 1983. Longevity of conidia of Sirococcus clavigignentijuglandacearum in a simulated airborne state. Phytopathology 73:1628-1631.

33. Tisserat, N., and Kuntz, J. E. 1984. Butternut canker: Development on individual trees and increase within a plantation. Plant Dis. 68:613616.

34. Untergrasser, A., Hijveen, H., Rao, X., Bisseling, T., Geurts, R., and Leunissen, J. A. M 2007. Primer3Plus, an enhanced web interface to Primer3. Nucleic Acids Res. 35:71-74.

35. Vincelli, P., and Tisserat, N. 2008. Nucleic acid-based pathogen detection in applied plant pathology. Plant Dis. 92:660-669.

36. Weising, K., Nybom, H., Wolff, K., and Meyer, W. 1995. DNA isolation and purification. In DNA Fingerprinting in Plants and Fungi. CRC Press, Boca Raton, FL.

37. White, T. J., Bruns, T., Lee, S., and Taylor, J. 1990. Amplification and direct sequencing of fungal ribosomal RNA genes for phylogenetics. Pages 315-322 in: PCR Protocols: A Guide to Methods and Applications. M. A. Innis, D. H. Gelfand, J. J. Sninsky, and T. J. White, eds. Academic Press, New York.

38. Zeng, Q. Y., Hansson, P., and Wang, X. R 2005. Specific and sensitive detection of the conifer pathogen Gremmeniella abietina by nested PCR. BMC Microbiol. 5:9. 